\title{
Chapter 1 \\ Migration and Access to Welfare Benefits in the EU: The Interplay between Residence and Nationality
}

\author{
Daniela Vintila and Jean-Michel Lafleur
}

\subsection{Introduction}

Against a general background of increasing ethnic diversity, strong politicisation of migration, and overexposure of mobile individuals to social risks, the access of migrants and their offspring to welfare has become a key area of concern across European democracies (Ruhs and Palme 2018). Especially in the context of the recent financial crisis, high levels of unemployment and rapidly growing poverty rates have led to an increased demand on welfare systems. At the same time, many countries have undertaken reforms to curb social expenditure, cut the levels of social benefits and/or restrict the pool of potential beneficiaries of welfare entitlements. Examples in this regard are the reductions of budgetary expenditure on welfare, the cut/freeze of public sector pay or pensions, the increase of retirement age, or the reduction of unemployment benefits that several European Union (EU) Member States adopted in recent years. ${ }^{1}$

This specific socio-economic context has had serious implications on the number of individuals in need of social protection, with certain groups facing strong economic hardship. Migrants have been particularly affected by the recent economic \footnotetext{
Social-dimension-of-austerity-measures.pdf. Accessed 16 March 2020.

D. Vintila $(\bowtie)$

Centre for Ethnic and Migration Studies (CEDEM),

University of Liege, Liege, Belgium

e-mail: Daniela.Vintila@uliege.be

J.-M. Lafleur

FRS-FNRS \& Centre for Ethnic and Migration Studies (CEDEM),

University of Liege, Liege, Belgium

e-mail: JM.Lafleur@uliege.be
}

${ }^{1}$ European Parliamentary Research Service (2013). Social dimension of austerity measures: cases of 4 EU countries in receipt of financial assistance. http://www.europarl.europa.eu/ep library/ 
crisis. According to the Eurostat migrant integration statistics ${ }^{2}$, half of non-EU citizens aged 20-64 years old residing in the EU in 2017 were considered at risk of poverty or social exclusion, compared to almost $28 \%$ among mobile EU citizens and 22\% for non-mobile Europeans, respectively. Moreover, severe material deprivation was twice as high for third-country nationals (hereafter TCNs) when compared to EU citizens. Being in work does not necessarily act as a safety tool against poverty: in 2017, one in five foreigners working in the EU suffered from in-work poverty. ${ }^{3}$ Of course, foreigners are not the exclusive targets of welfare policy reforms. Since the end of the twentieth century, EU Member States have indeed moved from passive income payments to active employment measures within social protection systems (Larsen 2005). This entails that all recipients of welfare entitlements - independently of their nationality — should now demonstrate some form of deservingness to receive such support.

In the context of the 2008 economic crisis and the growth in the arrival of asylum seekers around 2015, migrants' access to welfare has become increasingly salient in political discourses and at the societal level across the EU. According to the European Social Survey (ESS) data ${ }^{4}$, in 2016, more than 40\% of ESS respondents considered that immigrants should be granted access to social rights only after they have worked and paid taxes for at least a year, whereas almost 30\% supported the idea of granting social benefits only to naturalised migrants. These negative attitudes towards migrants' access to social protection have also been coupled by increasing politicisation of the effect of international migration on welfare systems (Schmidt et al. 2018). Consequently, several governments across Europe have put forward policy proposals aiming to limit migrants' eligibility for welfare benefits, whereas the argument of migrants as "abusers" or "unreasonable burden" for domestic social protection systems has often gained salience in political discourses (Lafleur and Stanek 2017; Ruhs and Palme 2018).

These recent socio-political dynamics have attracted an increasing scholarly interest in mobility-driven inequalities in access to social protection. While a rapidly growing body of scholarship has explored how the strong supranational framework of EU social security coordination affects intra-EU migrants' access to benefits (Martinsen 2005; Blauberger and Schmidt 2014; Kramer et al. 2018; Schmidt et al. 2018), little is known so far about the procedures, scope and extension of welfare entitlements for third-country nationals across the $\mathrm{EU}^{5}$. The knowledge on the array of social benefits that states make available to foreigners has also been predominantly restricted to case studies, with relatively little evidence of larger crossnational research (see Holzmann et al. 2005; Sainsbury 2006; Sabates-Wheeler and

\footnotetext{
${ }^{2}$ Eurostat (2019). Migrant integration statistics- at risk of poverty and social exclusion (data code: ilc_peps05). https://ec.europa.eu/eurostat/statistics-explained/index.php?title=Migrant_integration_statistics_-_at_risk_of_poverty_and_social_exclusion. Accessed 16 March 2020.

${ }^{3}$ Eurostat (2019). See Footnote 2.

${ }^{4}$ ESS Round 8 Data (2016). https://www.europeansocialsurvey.org/download. html?file=ESS8e02_1\&y=2016. Accessed 16 March 2020.

${ }^{5}$ European Migration Network. (2014). Migrant access to social security and healthcare: policies and practices. Brussels: European Commission
} 
Feldman 2011). Furthermore, since migrants' access to welfare has been traditionally studied from the perspective of receiving states, the critical role that sending states could play in protecting their nationals abroad against exposure to social risks is still understudied (Gamlen 2008; Lafleur 2013; Levitt et al. 2017).

This book is part of a series of three volumes (see also Lafleur and Vintila 2020a, b) that seek to address this research gap by providing a comprehensive cross-country comparison of social policies and programs targeting individuals in situation of international mobility. The book adopts a top-down analytical approach of the concept of migrant social protection, thus aiming to address the following questions: What type of access to social protection do migrants have across European countries? What kind of social benefits can they claim in their host countries and what type of welfare entitlements can they export from sending states? Do some migrant groups benefit from an easier formal access to such benefits than others? More precisely, what difference of treatment, if any, do EU Member States operate between EU migrants and third-country nationals beyond EU legislation? Lastly, are some countries more inclusive than others when it comes to social protection regimes for immigrants and emigrants alike?

To address these questions, this volume provides an in-depth analysis of social protection policies that EU Member States make accessible to national residents, non-national residents, and non-resident nationals. This differentiation allows us to capture different scenarios in which the interplay between nationality and residence could lead to inequalities in access to welfare. By bridging two bodies of literature social policy research and migration studies - in an innovative way, this book aims to shed light on the changing nature of European welfare states as a result of the intensification and diversification of migration processes and trajectories. The book also addresses a major fragmentation in the academic scholarship on migrants' access to welfare. Social policy scholars frequently overlook the specific barriers that apply to migrants (nationality, duration of stay or prior contributions, family split across borders, etc.) upon trying to access welfare in home or host countries (Morissens and Sainsbury 2005). Similarly, they tend to overlook the fact that migrants often maintain relations with other welfare states in which they may have contributed in the past and/or from which they may still benefit from certain level of protection despite their physical absence. More recently, migration scholars have tried to overcome this difficulty by using the concept of transnational social protection to examine cross-border strategies by which migrants combine welfare entitlements from home/host countries with informal strategies (via transnational solidarity networks, migrant associations, etc.) to address their social protection needs or the needs of their relatives (Barglowski et al. 2015; Levitt et al. 2017; Serra Mingot and Mazzucato 2017; Lafleur and Vivas Romero 2018). In this process, scholars have stressed the need to examine the interactions between sending and receiving states' welfare configurations, but tended to use a case-studies approach that does not allow for systematic comparisons across states and/or different categories of mobile individuals.

In highlighting the multiple areas of state intervention towards migrant populations, we rely on a comparative research design that examines welfare entitlements 
across EU $27^{6}$. For each country, we systematically analyse migrants' access to benefits across five policy areas: health care, unemployment, old-age pensions, family benefits, and guaranteed minimum resources. Each case study maps the eligibility conditions for accessing welfare, by paying particular attention to the type of benefits that migrants can claim in host countries and/or export from home countries. The chapters included in this volume discuss the legislation regulating access to benefits in kind and cash, the legal definition of beneficiaries, the eligibility conditions applied for each benefit, and the period for which these benefits are granted. Each case study also provides an assessment of recent trends and directions in accessing welfare across the five policy areas of interest.

\subsection{Challenging the Welfare State in an Era of International Mobility: What Type of Social Protection Regimes for Mobile Individuals?}

Historically, welfare states have been designed as closed systems in which a group of people agree to share public goods (Walzer 1983). As citizenship has been the main criteria to define membership to this group, resident citizens in need were traditionally considered as an uncontested category of recipients of welfare entitlements. Yet, as noted by Freeman (1986), the coincidence between citizenship and the right to welfare has never been perfect. In the EU in particular, international mobility has not only challenged the principle of citizenship, but also that of territoriality according to which one had to be a resident to access social benefits. This trend has become visible since the end of World War II, with the development of the European integration process and the signature of bilateral labour agreements with third countries. The 1957 Rome Treaty ${ }^{7}$, in particular, acknowledged that, to convince people to move, the principle of free movement of workers had to be associated with some form of openness of welfare systems towards foreigners as well as increased coordination between states in the area of welfare. Whereas the development of EU citizenship, the rulings of the Court of Justice of the European Union and the adoption of the EU legislation on social security coordination ${ }^{8}$ have

\footnotetext{
${ }^{6}$ For an overview of migrants' access to social protection in the United Kingdom, see Lafleur and Vintila (2020b) in this series.

${ }^{7}$ See https://eur-lex.europa.eu/legal-content/EN/TXT/?uri=LEGISSUM\%3Axy0023. Accessed 16 March 2020.

${ }^{8}$ See Regulation (EC) No. 883/2004 of the European Parliament and of the Council of 29 April 2004 on the coordination of social security systems (https:/eur-lex.europa.eu/legal-content/EN/ ALL/?uri=CELEX:32004R0883- accessed 16 March 2020) and Regulation (EC) No. 987/2009 of the European Parliament and of the Council of 16 September 2009 laying down the procedure for implementing Regulation (EC) No. 883/2004 on the coordination of social security systems (https://eur-lex.europa.eu/legal-content/EN/ALL/?uri=CELEX:32009R0987- accessed 16 March 2020).
} 
progressively expanded the access of mobile EU citizens to other categories than workers, states have tried to ensure that access to welfare remains primarily determined by a direct relation between individuals and Member States, rather than the EU (Maas 2007; Lafleur and Mescoli 2018).

In this chapter, we argue that migration to, within and from the EU is contesting the boundaries between insiders and outsiders in social policy legislations in two ways. First, by posing increasing pressures on host countries (especially those receiving large migration inflows) to extend access to social benefits beyond the closed group of nationality holders. This had led to discussions vis-à-vis the openness of post-national welfare state models (Bommes and Geddes 2000; Schmitt and Teney 2019) and the necessity to grant residence-based welfare rights to foreigners, especially those contributing to the social security system of their host countries via employment and taxes (see also Guiraudon 2002). Secondly, drawing on efficiency and fairness considerations, sending countries also started to witness increasing demands to ensure the (ex)portability of social benefits for their non-resident populations (Holzmann 2016). This includes not only their nationals abroad (under the rationale of a nationality-driven obligation for protecting the diaspora), but also foreigners who accumulated social security rights in these countries and later decided to return to their origin countries.

Nonetheless, these mobility-driven demands for exportability of social benefits and the recognition of non-national residents as eligible claimants of welfare assistance have quickly faced several counter-arguments. In the case of emigrants, their exclusion as beneficiaries of social benefits has been justified by the fact that they are no longer contributing to the welfare system of their home countries. Hence, when exportability is allowed, it generally covers only contributory benefits for those who comply with qualifying periods of prior contributions, thus justifying their prior economic commitment with their countries of nationality. When it comes to immigrants, the main debate has evolved around the idea that migration could represent a "burden" for the host welfare system, thus allegedly posing a threat especially for generous welfare regimes (Sainsbury 2006; Römer 2017; Ruhs and Palme 2018; Schmidt et al. 2018). This framing of migration and welfare relies on two assumptions. On the one hand, it assumes that welfare states that offer a wider range of easily accessible and generous benefits are necessarily more exposed to the potential fiscal impact of migration. This mainly derives from the "welfare magnet hypothesis" according to which generous welfare policies lead to increased immigration (Borjas 1998). Independently of the mixed evidence found in this regard (Giulietti 2014), the idea that migrants generally take out more from the welfare system than they put in via taxes is still well-engrained in the public opinion across developed economies 9 . It also justifies policy-makers' use of the so-called "no recourse to public funds for migrants" mantra (Deacon and Nita 2013), i.e. the idea that, to avoid further immigration, social policy reforms should limit

\footnotetext{
${ }^{9}$ See ESS results, Round 7 (2014). https://www.europeansocialsurvey.org/data/download. html?r=7. Accessed 16 March 2020.
} 
immigrants' access to social protection. Such perceptions, however, deny the existence of large differences between states in the way they deal with mobility in access to social benefits. In other words, it is not only the width of policies or the budget dedicated to them that matters, but also the specific eligibility conditions applied to mobile individuals when they try to access benefits. Moreover, this approach also overemphasizes the role of welfare states as social protection providers for residents (nationals and non-nationals), but neglects that, beyond the EU framework and bilateral/multilateral arrangements between sending and receiving states, important discrepancies may still exist in the way states respond to the social protection needs of their nationals abroad.

In parallel with these pressures for the redefinition of access to welfare at the domestic level, international mobility has also become an important driver for increasing social security cooperation between states (Avato et al. 2010). This cooperation mainly aims to regulate the types of social benefits that specific migrant groups can access due to their links to several national welfare systems. Yet, this type of cooperation can take different forms. On the one hand, the inclusiveness of domestic welfare regimes towards migrants is often conditioned by the existence of bilateral/multilateral social security agreements between home and host countries. These agreements sometimes put certain nationalities in a more privileged position to access welfare from their host countries. In the EU, despite the efforts to coordinate Member States' social security agreements with third countries, important variations still exist in the level of social security cooperation with the home country authorities of TCNs residing in EU countries (Eisele 2018). On the other hand, the inclusiveness of national welfare regimes has also been significantly shaped, in recent years, by the adoption of international norms recommending or guaranteeing portability of rights and/or equal treatment provisions. At the global level, examples include the International Labour Organization (ILO) Conventions and Recommendations ${ }^{10}$ or the 1990 United Nations (UN) Convention on the Rights of Migrant Workers ${ }^{11}$. Regional agreements may also set rules regulating social security cooperation between groups of states. The most advanced scheme in this regard is the EU social security coordination. Together with the extensive jurisprudence of the Court of Justice of the EU, the EU coordination often guarantees that mobile EU citizens have an easier access to social benefits compared to TCNs, while also limiting states' margin of manoeuvre in freely regulating EU migrants' access to welfare (Seeleib-Kaiser and Pennings 2018; Schmidt et al. 2018).

\footnotetext{
${ }^{10} \mathrm{https}$ ://www.ilo.org/global/standards/introduction-to-international-labour-standards/conventions-and-recommendations/lang\%2D\%2Den/index.htm. Accessed 16 March 2020.

${ }^{11}$ https://www.ohchr.org/EN/ProfessionalInterest/Pages/CMW.aspx. Accessed 16 March 2020.
} 


\subsubsection{Existing Typologies of Immigrant Social Protection Regimes}

Until recently, there has been limited academic effort to map out migrants' access to social protection via large-N comparisons of different countries and groups of mobile individuals. Some scholars have approached this topic via small-N comparisons of selected countries (Bommes and Geddes 2000; Sabates-Wheeler and Koettl 2010; Sainsbury 2012). Others have focused only on the welfare entitlements of specific groups, such as immigrants (Sainsbury 2006; Römer 2017; Schmitt and Teney 2019), thus neglecting that migrants are often entitled to social rights also from their origin countries. Finally, some scholars have recently tried to classify the immigrant population worldwide based not only on their access to social protection in the host country, but also the portability of their rights across borders.

Holzmann et al. (2005) and later, Avato et al. (2010), in particular, built and refined a typology of four immigrant social protection regimes focusing on the host country legislation towards immigrants and bilateral/multilateral agreements concluded between home and host countries. Drawing on the original typology of Holzmann and colleagues, Avato et al. (2010) used existing databases on migration flows to determine the share of global migration covered by each regime. Their results demonstrate that few migrant groups (mainly those moving between wealthy nations of the North) are under the most favourable regime (Regime I) allowing them to access social benefits in the host country, while being able to export some benefits due to bilateral/multilateral arrangements. Most migrants find themselves in Regime II in which they can access the host welfare system without the possibility to totalize contribution periods in absence of bilateral agreements. Under Regime III (predominant in the Gulf countries), documented migrants cannot access the host country's welfare system, but specific and limited rights may be granted on an ad-hoc basis. Lastly, under Regime IV, undocumented migrants are very exposed to social risks as, in addition to their exclusion from welfare schemes, their exclusion from the formal labour market also prevents them from accessing work-related protection.

These efforts to classify immigrant social protection regimes represent a major step forward in merging migration research and social policy literature, especially since they recognize that-in line with socio-anthropological work on transnational migration-migrants do not cut links with the home country upon moving abroad. However, they also face several limitations that question their validity and applicability for all migrant groups across different home and host countries. Firstly, existing typologies do not actually detail the specific conditions under which migrants can access social benefits, as they mostly focus on the existence of a nondiscrimination principle in accessing welfare. Yet, the mere existence of nondiscriminatory regulations does not necessarily guarantee that migrants are well protected against vulnerability, nor that they can easily access welfare. Even when equal treatment provisions are in place (a scenario that would probably fall under Regime I according to previous typologies), migrants may still find it very hard to claim social benefits simply because the eligibility conditions applied for those benefits are quite restrictive, regardless of claimants' nationality. Thus, the existence of 
a social security agreement per se and the equal treatment provision stipulated in it do not act as a guarantee that migrants will, indeed, have formal access to welfare, nor that benefit provisions adequately respond to their needs.

Secondly, existing typologies only provide a snapshot of access to specific benefits - especially pensions or health care in Holzmann et al. (2005), rather than operationalizing social protection in a more comprehensive manner. While it is true that accessing health care in the host country or having the possibility to export pensions could have a crucial impact on migrants' socio-economic vulnerabilities, these specific benefits only capture a limited picture of the whole array of welfare provisions that individuals may be entitled to when crossing the borders of different countries. As shown in this volume, migrants also have access to other traditional branches of social protection - including unemployment benefits, family-related benefits or social assistance services- that are equally important for preventing poverty and social risks. Consequently, the focus on a very narrow scope of welfare rights could lead to a rather distorted picture of the reality in terms of how well protected migrants are by national and international legislations. This becomes particularly evident when looking at old-age contributory pensions. As highlighted in the country chapters in this volume, unlike other social security branches, old-age pensions have subscribed to a trend of liberalization in terms of (ex)portability across social security systems, due to increased cooperation between states.

Thirdly, it is rather unclear how existing typologies have captured and aggregated different sub-categories of social benefits that migrants may have access to across specific policy areas. For instance, their measurement of health-related entitlements seems limited only to benefits in kind, while omitting the cash benefits granted in case of sickness. Similarly, their focus on pensions is exclusively defined within the framework of contributory old-age financial compensations, while neglecting that several countries also grant non-contributory allowances aiming to prevent poverty among the elderly population (see the examples of Austria, Belgium, Cyprus, Finland, Italy or Sweden in this volume). This seems particularly relevant since the specific conditions under which migrants can access non-contributory pensions as well as the overall scope, rationale and possibility of exportability of these pensions, are quite different when compared to the contributory ones.

Fourthly, by giving considerable weight to portability of benefits back to the home countries, previous typologies seem rather focused on a particular migrant group, namely those who have the intention to return after having lived abroad. Yet, not all migrants share this migration trajectory and for many of them, the option of return is not even a desirable one. For all those who find themselves in this scenario, the importance of (ex)portability of social benefits could fade away when compared to the relevance of their more immediate access to welfare in the host country (or when compared to their entitlement to social rights from the home country while residing abroad). Thus, apart from potentially overestimating the importance of return for migrants' life plans, these typologies might also underestimate the need for social protection that individuals actually have during their stay abroad (which in many cases, implies a quite long time span). 
Additionally, previous typologies do not seem to address in detail how the general inclusiveness and development of welfare states could shape countries' behaviour towards emigrant and immigrant populations. As an illustration, migrants may receive limited social benefits in a particular country not because of their status of mobile individuals, but because that country offers limited benefits to all residents, including national citizens. At the opposite pole, when a regime is classified as generous towards migrants, this does not necessarily indicate that policy-makers are particularly concerned with addressing their social vulnerability. It can simply be a direct consequence of the inclusiveness of that regime towards all residents in general, regardless of their migration status. Lastly, in some cases, previous typologies also put forward some speculative assumptions that may lead to an oversimplification of social protection legislations. By way of example, Holzmann et al. (2005) assume that migrants originating from countries that have concluded a bilateral social security agreement (BSSA) with their host country fall under Regime I of advanced portability. Yet, the mere existence of bilateral agreements does not directly imply that they also cover all types of social benefits (see also Holzmann 2016 and several chapters in this volume); and the classification of these cases under Regime I may overestimate how inclusive and prevalent this regime is.

\subsubsection{Welfare Entitlements for Mobile Individuals: An Alternative Operationalization}

This book aims to address some of the limitations of previous studies on immigrant social protection regimes. To begin with, we adopt a comprehensive definition of social protection by covering a wide range of social benefits. Drawing on the definitions used by the European Commission's Mutual Information System of Social Protection (MISSOC) ${ }^{12}$, we provide an inventory of contributory and noncontributory benefits across five policy areas: unemployment (covering unemployment insurance and assistance benefits) ${ }^{13}$; old-age contributory and non-contributory pensions ${ }^{14}$; family-related benefits (maternity, paternity, parental and child benefits) ${ }^{15}$;

\footnotetext{
${ }^{12} \mathrm{http}: / /$ ec.europa.eu/social/main.jsp?catId=815\&langId=en. Accessed 16 March 2020.

${ }^{13}$ Unemployment insurance benefits depend on a qualifying period of paid contributions, whereas unemployment assistance benefits are generally means-tested and granted to those who do not qualify (no longer qualify) for unemployment insurance benefits.

${ }^{14}$ Contributory old-age pensions are granted to individuals who have reached retirement age and/ or sufficient years of contributions, whereas non-contributory pensions aim to prevent poverty and provide a safety net for the elderly population with little or no contribution history.

${ }^{15}$ Maternity and paternity benefits cover absence from work due to the birth of a child. Parental benefits usually start after the maternity/paternity benefits come to an end and they generally aim to cover parents' absence from work to take care of their children. Child/family benefits cover the costs incurred in bringing up children. Different eligibility conditions might apply for same-sex couples, registered partners, adoptive parents, etc.; but these specific situations are not discussed in this volume.
} 
guaranteed minimum resources ${ }^{16}$; and health-related benefits (sickness benefits in kind and cash, and invalidity benefits) ${ }^{17}$. In doing so, we aim to capture cross-country variations in states' likelihood to extend certain benefits to migrants, with one key expectation being that contributory benefits (directly deriving from social security contributions) are more easily made available to mobile individuals when compared to non-contributory benefits.

Secondly, this book enquires about the conditions of access to social benefits for five different groups of potential beneficiaries: a) national residents; b) EU foreign residents; c) non-EU foreign residents; d) EU nationals residing abroad in other EU Member States and; e) EU nationals residing abroad in non-EU countries. Thus, we systematically compare the inclusiveness of social protection systems towards immigrants and emigrants alike; and we further assess how protected migrants are in home and host countries by comparing the benefits they are entitled to with the ones available for resident nationals. This comparison between groups aims to capture not only potential gaps in access to welfare between migrant and non-migrant populations; but it also aims to test states' predisposition towards a residence-based access to social benefits versus a nationality-driven rationale of access to welfare. In the case of non-national residents and non-resident nationals, we also distinguish between those originating from (or going to) EU Member States and third countries. This distinction draws from our expectation that the EU coordination framework may grant mobile EU citizens an easier access to benefits when compared to migrants going to or coming from non-EU countries, especially since most social benefits analysed here fall in the field of application of EU coordination regulations ${ }^{18}$. Our analysis specifically excludes certain migrant groups whose access to welfare could be conditioned by their specific status: tourists, individuals during short stays abroad of less than three months, undocumented migrants, students, civil servants, asylum seekers, refugees, posted workers, family members, seasonal workers. The data collection was based on a survey with national experts conducted in the framework of the ERC-funded project "Migration and Transnational Social Protection in (Post) Crisis Europe" (MiTSoPro). ${ }^{19}$ National experts were asked to complete five questionnaires (one per policy area) detailing the eligibility conditions for accessing welfare in each country, based on national and/or international

\footnotetext{
${ }^{16}$ Also referred to as "integration/insertion income", "social assistance", "income support", etc. Generally, these are means-tested benefits conceived as the last safety net, aiming to prevent households from poverty. We mainly discuss general/non-categorical assistance schemes aiming to guarantee a minimum income to all those in need, although some countries might also provide specific schemes of categorical assistance for specific groups.

${ }^{17}$ Whereas benefits in kind cover access to doctors, hospitalisation or treatment, sickness cash benefits and invalidity benefits compensate individuals for the loss of income due to sickness/the loss of the capacity to work.

${ }^{18}$ See Regulation (EC) No 883/2004 and Regulation (EC) No 987/2009.

${ }^{19} \mathrm{http}: / /$ labos.ulg.ac.be/socialprotection/ (accessed 16 March 2020). The survey was conducted between April 2018-January 2019, with several rounds of consistency checks being centrally conducted by the MiTSoPro team. Given the period in which the survey was conducted, the country chapters included in this volume focus mainly on the policies in place at the beginning of 2019.
} 
legislation. The survey included standardised questions, thus ensuring comparability across the countries analysed, despite their different welfare regimes, political settings and migration histories.

Thirdly, the book maps out migrants' access to social protection across EU27. Increasing migration to and from the EU, coupled with incremental supranational social security initiatives, make EU countries very relevant case studies for our purposes. Yet, not all EU Member States are expected to be equally concerned with the social protection needs of their foreign and diaspora populations. In fact, their different migration trajectories as well as the composition of their immigrant/emigrant communities are expected to significantly shape their policy responses and repertoires when it comes to the inclusion of these groups into domestic welfare systems. To begin with, there are still significant differences between those EU Member States traditionally considered as countries of immigration (hence potentially facing stronger demands for extending welfare to foreigners- see also Schmitt and Teney 2019) and those generally labelled as emigration countries (which, in turn, may be more pressured to respond to the needs of their diaspora). Western European countries usually fall in the first category, whereas many Central and Eastern European states (which also joined the EU more recently) are primarily seen as countries of emigration.

Given these different migration patterns, the demographic weight of non-national residents (Fig. 1.1) and non-resident nationals (Fig. 1.2) still varies widely across the EU. In nine countries (Belgium, Ireland, Germany, Austria, Latvia, Estonia, Malta, Cyprus, and Luxembourg), foreigners account for more than $10 \%$ of the population, with the highest share (48\%) being observed in Luxembourg. However, in Poland, Bulgaria, Romania, Slovakia, Lithuania or Croatia, the share of foreigners is quite low (1\% or less of the population), reason for which these countries would presumably receive less demands to ensure foreigners' access to welfare. Similarly, countries such as Croatia, Ireland, Portugal, Lithuania, Romania, Latvia, Cyprus, Luxembourg, Estonia or Bulgaria count with sizeable diasporas, thus being expected to be particularly responsive to the social protection needs of their nationals abroad, when compared to countries in which the proportion of non-resident nationals is much more limited (Fig. 1.2).

Drawing on the demographic weight of immigrant and emigrant populations, Fig. 1.3 sums up the expected societal demand that EU Member States may face for including these groups in their domestic welfare systems. Several clusters emerge, from countries which a priori could face stronger pressures for opening their welfare systems to both immigrants and emigrants (Estonia, Cyprus, Luxembourg, Latvia, Ireland, Malta), to countries in which this pressure for responsiveness is expected to be much more limited due to their limited shares of non-national residents and non-resident nationals (the Czech Republic). Moreover, countries in which only one of these groups is particularly sizeable are expected to face stronger claims for inclusion of immigrants only (Belgium or Spain) or emigrants only (Bulgaria, Romania, Lithuania, Portugal, Poland, Croatia or Slovakia). Finally, some countries may face more moderate demands for opening their welfare system to any (or both) of these groups. 


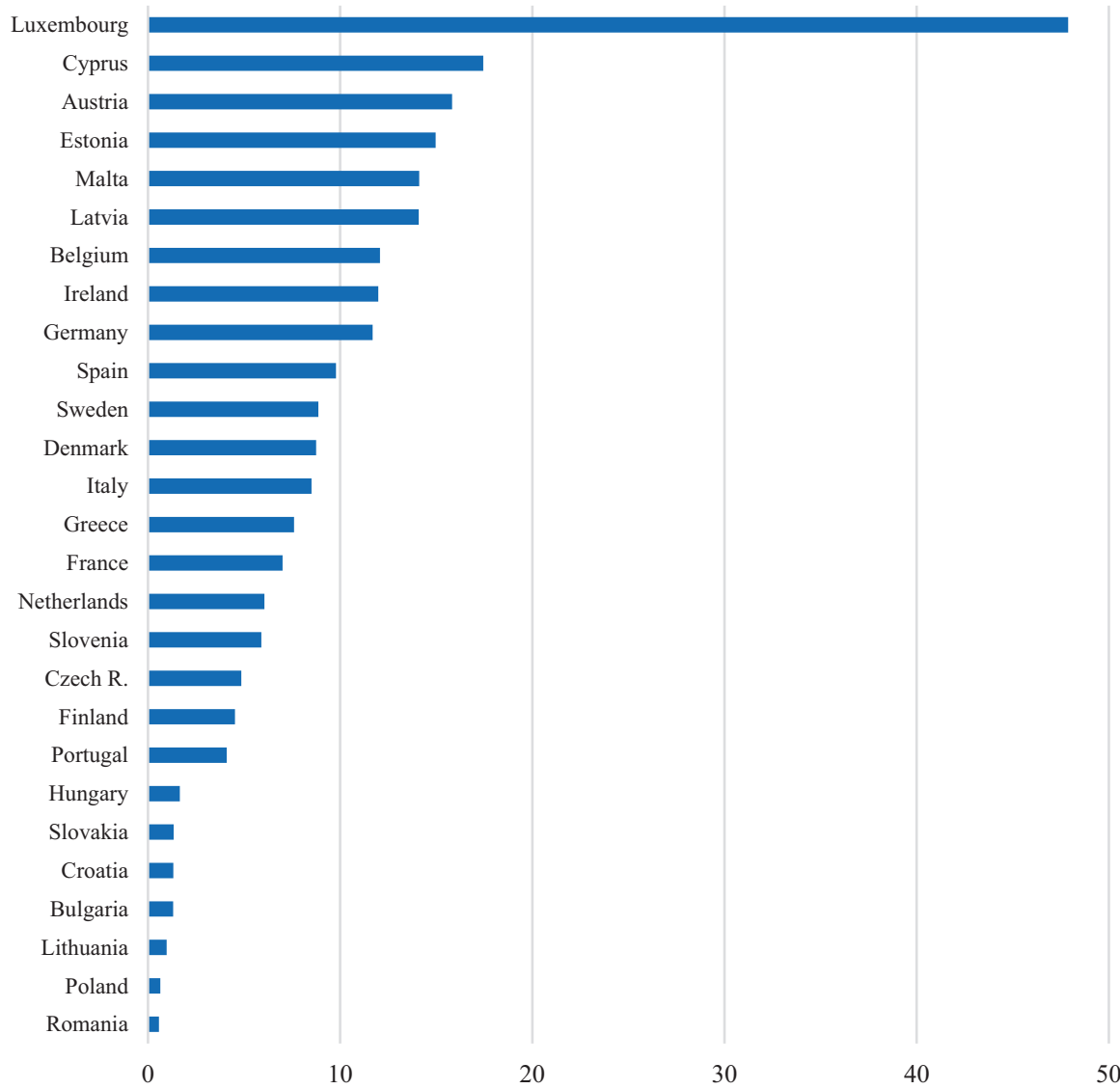

Fig. 1.1 EU Member States by share of foreigners over total population. (Source: Own elaboration based on Eurostat data- Population on 1 January by age group, sex and citizenship- 2018 [migr_pop1ctz], https://ec.europa.eu/eurostat/data/database. Accessed 16 March 2020)

In terms of how states react to the social protection needs of these groups, one reasonable expectation would be that the more sizeable immigrant or emigrant communities are, the more likely it is for their needs and demands to be incorporated in the political agenda and, implicitly, the higher the likelihood of states to ensure their access to national welfare systems. Drawing on this rationale, countries counting with large migrant groups could become particularly concerned with their social protection in response to this demographic visibility, thus granting them access to welfare entitlements. In turn, EU Member States in which the stocks of immigrants and/or emigrants are considerably smaller would be less motivated to become particularly inclusive towards these communities. Yet, a reversed reaction is also likely to emerge, especially if states ponder the anticipated costs of their policies in the decision to grant or not welfare benefits to non-nationals or non-residents. When these groups are relatively small, ensuring their access to welfare may result in a 


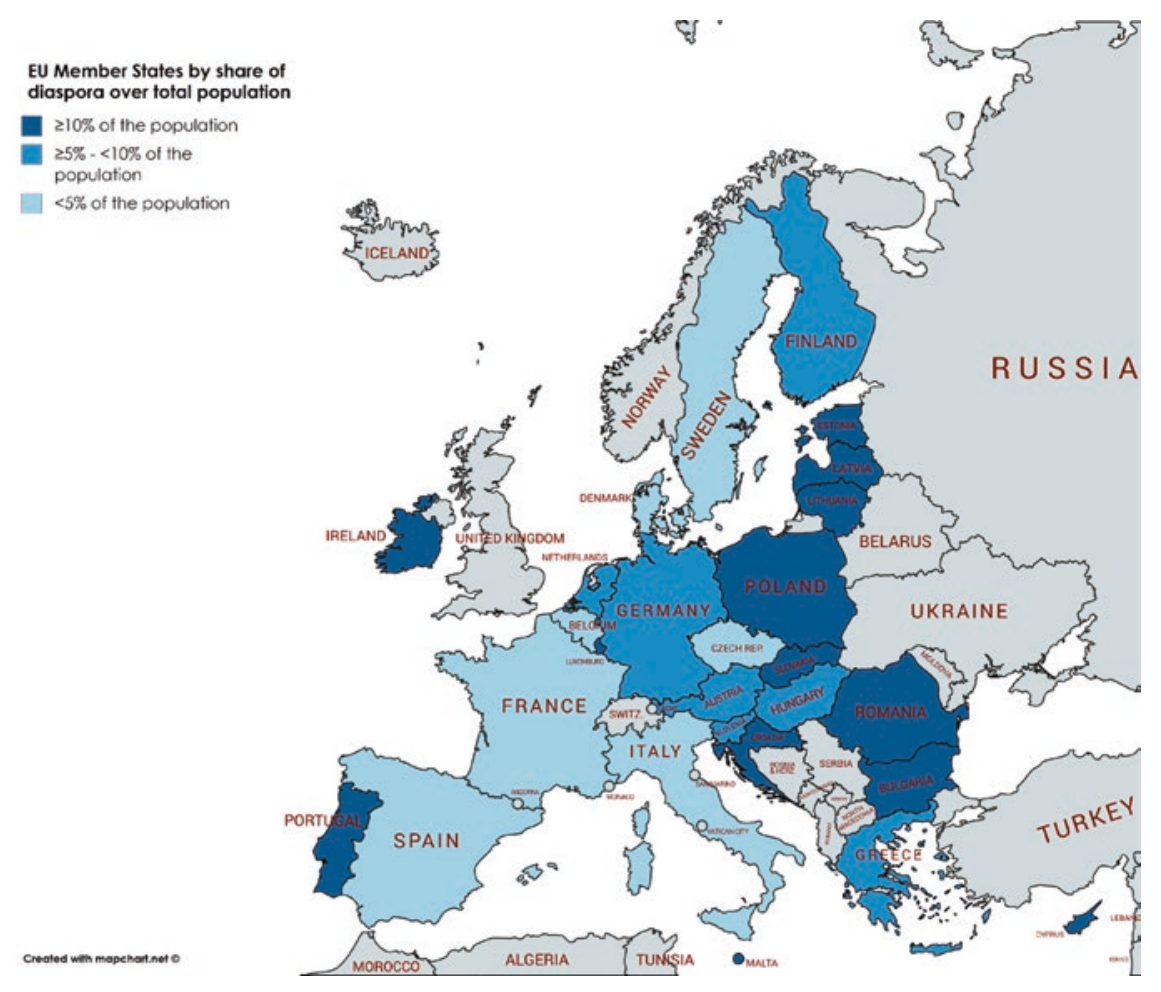

Fig. 1.2 Relative size of diaspora populations (share of non-resident nationals over total population). (Source: Own elaboration based on OECD data. The data on diaspora stocks is from OECD (2015) "Connecting with emigrants: a global profile of diasporas 2015" and it refers to the emigrant population aged $15+$ across 84 selected destinations (33 OECD countries and 51 non-OECD states). For Malta and Cyprus, the stocks of diaspora are from the DIOC-E 2010/2011 Labour Force Status dataset, covering emigrant population aged 15+ across 87 destinations (35 OECD countries and 52 non-OECD states). The data on total population is from the OECD Historical Data file (population 15+, reference year 2010, https://stats.oecd.org/Index. aspx?DataSetCode=POP_PROJ\#, accessed 16 March 2020))

low-cost political decision, as few individuals would potentially qualify as eligible applicants. Moreover, adopting such policy would not only be feasible due to limited costs involved, but it could also come with a symbolical reward for these countries' inclusiveness towards migrant groups. Conversely, when immigrant or emigrant populations are particularly sizeable, the decision to grant them access to the national welfare system - although much more meaningful in terms of impact- could involve significant economic costs. Consequently, states may be more hesitant to adopt such policy that comes with higher economic risks, given the larger pool of non-nationals and non-residents who could become entitled to claim welfare benefits.

Nevertheless, these initial expectations do not take into account the timing of migration inflows/outflows, nor the specific composition of migration stocks, two 


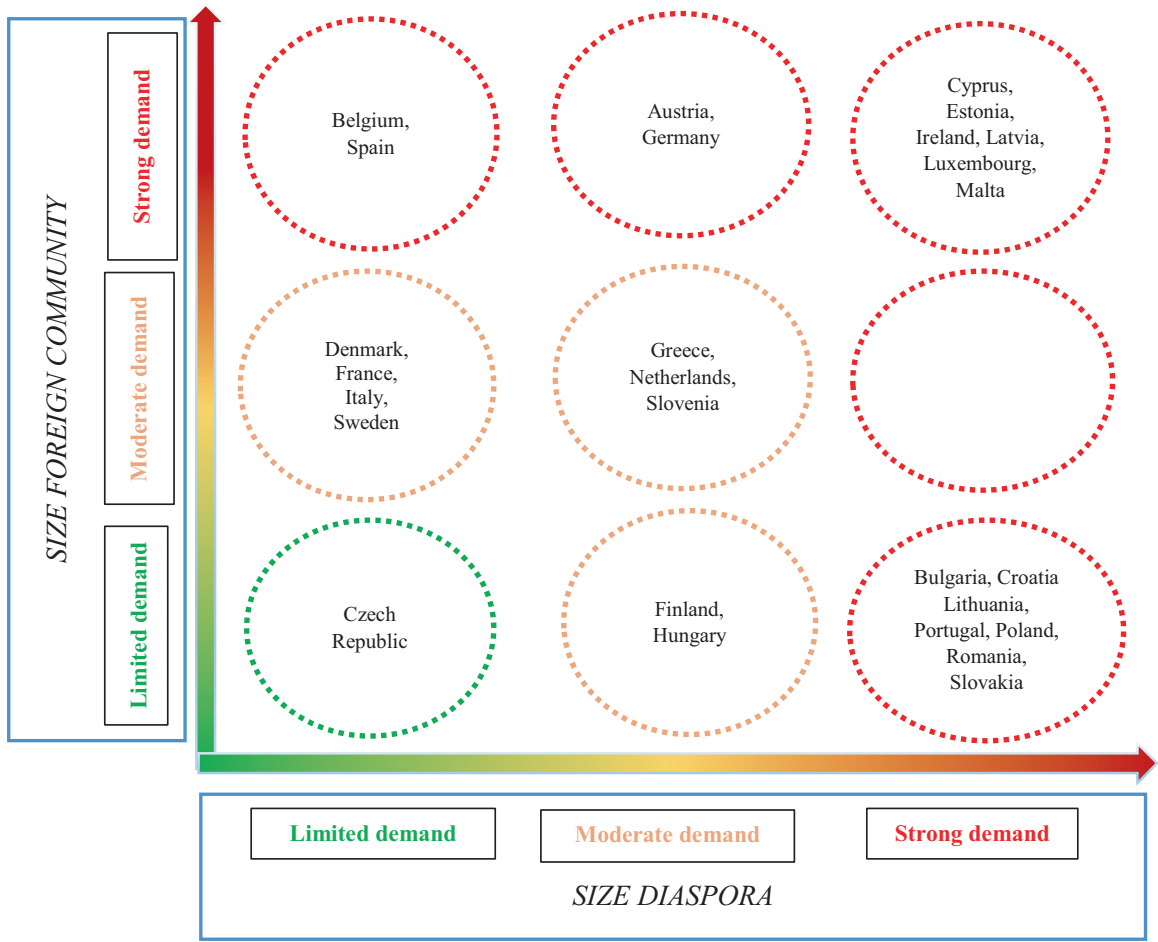

Fig. 1.3 Initial expectations regarding societal demands for states' responsiveness, based on the demographic size of immigrant and emigrant populations (\% of each group over total population). (Source: Own elaboration based on Eurostat data for immigrants and OECD data for emigrants (see detailed description of sources in Figs. 1.1 and 1.2 above). The vertical axis captures the expected demand that states may face for granting foreigners' access to welfare, based on the share of non-citizens over the total population: a) limited demand (countries in which foreigners represent $<5 \%$ of the population); b) moderate demand (foreigners account for $\geq 5-<10 \%$ of the population) and; c) strong demand (countries in which foreigners represent $\geq 10 \%$ of the population). The horizontal axis captures the expected demand that states may face to ensure the access of nonresident nationals to welfare, based on the share of the diaspora over the total population (same thresholds as for the vertical axis). Green indicates limited demand, orange indicates moderate demand, while red indicates that strong demand is anticipated)

elements that could be equally relevant for anticipating when (and how) states implement policies that allow foreigners and/or non-resident nationals to access their welfare system. Regarding timing, one can assume that long-standing countries of immigration may be more open to granting social rights to foreigners when compared to "new" countries of immigration (see Koopmans and Michalowski 2017 for a similar argument on how rights recognition could be linked to historical immigration legacies). Consequently, EU Member States with a longer immigration tradition (Germany, France, Belgium or the Netherlands, which started to receive substantial migration inflows after World War II) are expected to have implemented by now specific policies guaranteeing foreigners' access to welfare, when compared 
to countries which more recently started to attract international migrants (such as South European countries or Finland). Similarly, countries experiencing emigration waves for a long time (particularly Cyprus, Spain, Italy, Ireland or Portugal) are expected to be more inclined to pro-actively respond to the social protection needs of their citizens abroad when compared to more recent emigration countries (Poland, Romania or Bulgaria, among others). However, when it comes to countries with a longer tradition of emigration, it could also be the case that their diaspora population is already well settled abroad, with an extensive access to destination countries' welfare systems, and less need to rely on social benefits granted by origin countries. This, in turn, could reduce the need for an active intervention in the area of social protection from sending countries. Moreover, more recent emigrant communities may be precisely the ones requiring more social protection attention from their homeland, especially if they do not count with immediate access to the welfare system of their host countries.

As for the composition of migration stocks, the EU system of social security coordination and the principle of non-discrimination are expected to provide intraEU migrants with easier access to social benefits when compared to non-EU groups whose access to welfare usually depends on each EU host country ${ }^{20}$ and/or bilateral agreements concluded between EU Member States and third countries ${ }^{21}$. Consequently, one could expect that countries whose immigrant or emigrant populations mainly come from or go to other EU Member States have fewer incentives to adopt inclusive social policy programs towards non-residents or non-nationals, as most of them will, in any case, be protected by the EU framework in accessing welfare.

As shown in Fig. 1.4, non-national EU citizens account for more than a half of the foreign population in only eight EU countries (the Netherlands, Romania, Malta, Belgium, Ireland, Cyprus, Slovakia, and Luxembourg); whereas third-country nationals still form the majority of the stocks of foreigners across most EU Member States. However, most Europeans residing outside their countries of nationality are intra-EU migrants (more than $75 \%$ in the case of Luxembourg, Romania, Slovakia, Finland, Belgium or the Czech Republic). Only the diaspora populations of nine EU countries mainly reside in non-EU destinations.

Finally, the economic or political "leverage" that immigrant and emigrant communities have on home and host country governments could also influence states' decision to grant them welfare entitlements. As shown in Fig. 1.5, some emigrant

\footnotetext{
${ }^{20}$ Yet, see also Regulation No. 1231/2010 of the European Parliament and of the Council of 24 November 2010 extending Regulation No. 883/2004 and Regulation No. 987/2009 to nationals of third countries who are not already covered by these Regulations solely on the ground of their nationality (https://eur-lex.europa.eu/legal-content/EN/TXT/?uri=CELEX\%3A32010R1231, accessed 16 March 2020).

${ }^{21}$ See also COM (2012) 153 final- Communication from the Commission to the European Parliament, the Council, the European Economic and Social Committee and the Committee of the Regions- The External Dimension of EU Social Security Coordination, http://eur-lex.europa.eu/ LexUriServ/LexUriServ.do?uri=COM:2012:0153:FIN:EN:PDF. Accessed 16 March 2020.
} 


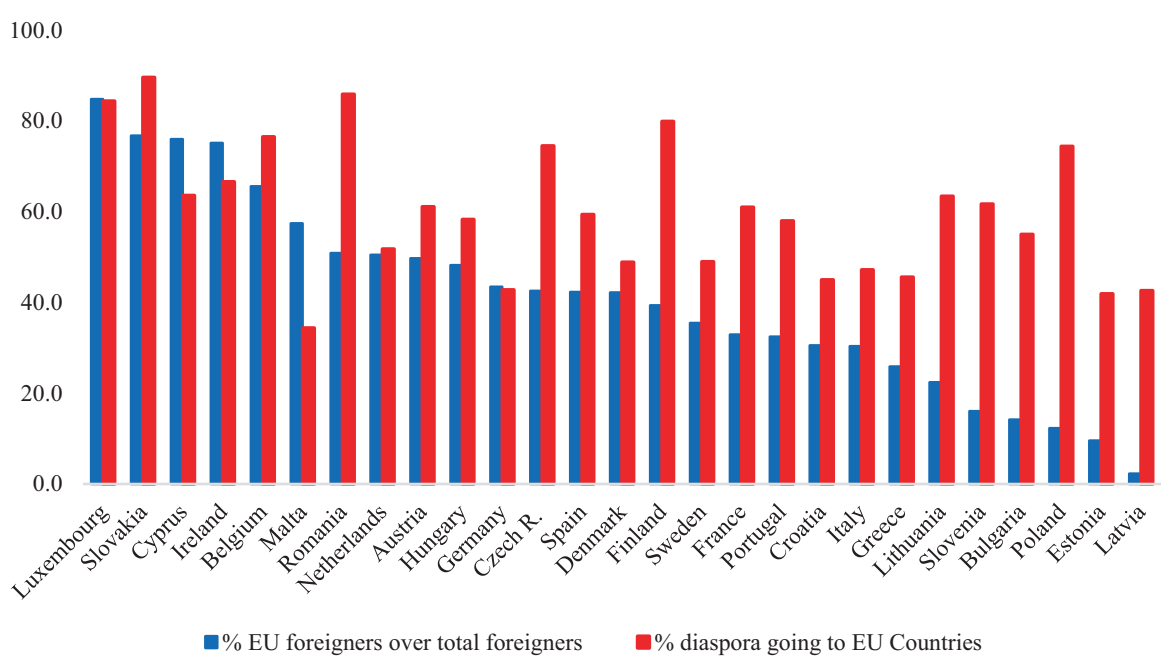

Fig. 1.4 Share of mobile EU citizens from the total foreign population and from the total diaspora of each EU Member State. (Source: Own elaboration based on the 2018 Eurostat data [migr pop1ctz] for foreigners and DIOC-E 2010/11 Labour Force Status data for nationals abroad (emigrant population aged $15+$ across 87 selected destinations))

communities can be seen as important economic actors for their homeland, as their remittances represent a substantial share of the Gross Domestic Product (GDP): 3\% for Hungary, Lithuania or Luxembourg; $4 \%$ in Bulgaria and Latvia; or even 5\% in Croatia. Consequently, these origin countries may be more incentivised to adopt specific policies for their nationals abroad when compared to other sending countries whose diaspora populations make more limited economic contributions (for instance, Italy, Germany, Finland or the Netherlands). Moreover, countries in which immigrants constitute a lower share of the workforce (especially Central and Eastern European countries, which return low shares of foreign-born workers over total employees) may be less likely to adopt specific policies for this group when compared to countries in which $15 \%$ or more of the workforce is foreign-born (Fig. 1.5).

In addition, the political leverage that these communities count with could also motivate policy-makers in home and host countries to become particularly responsive to their social protection needs. For instance, one could reasonably assume that countries in which immigrants and emigrants count with voting rights may be more prone to address their welfare demands in national legislations, especially if these communities are particularly large. The diaspora literature, in particular, has underlined how economic and electoral interests - among other factors - may push sending states' authorities to please citizens abroad with policies that respond to their needs (Gamlen 2008; Lafleur 2013). Similarly, scholars working on immigrants' voting rights postulated that foreigners' enfranchisement may trigger parties' responsiveness to immigrants' interests (Bird et al. 2011; Vintila and Morales 2018). Across the EU, all Member States recognize the right of mobile EU citizens to vote at local and European Parliament elections (Shaw 2007; Vintila 2015); and in some 


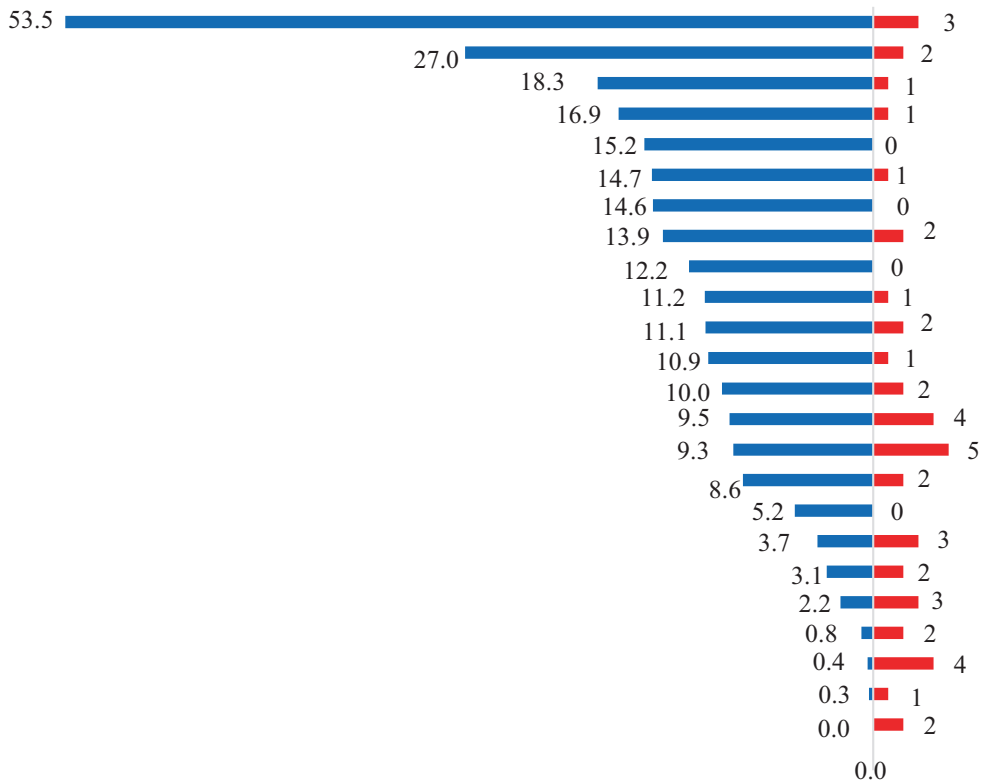

匹 \% foreign born over total employees $\quad$ Remittances as share of GDP

Fig. 1.5 EU countries by share of foreign-born over total employees and remittances as share of GDP. (Source: Own elaboration based on the 2014 Eurostat dataset Employee by migration status, educational attainment level, occupation and working time (lfso_14leeow, https://ec.europa.eu/ eurostat/data/database, accessed 16 March 2020) and the 2018 World Bank data on Migrant Remittances Inflows (https://www.worldbank.org/en/topic/migrationremittancesdiasporaissues/ brief/migration-remittances-data, accessed 16 March 2020))

countries (Croatia, Slovakia, Sweden or Hungary), they can also vote in regional elections. Some EU Member States also enfranchise all non-EU nationalities for local elections (Belgium, Denmark, Estonia, Finland, Hungary, Ireland, Lithuania, Luxembourg, the Netherlands, Slovakia, Slovenia, Sweden) and regional elections (Denmark, Hungary, Slovakia, Sweden); whereas others (Spain or Portugal) recognize electoral rights only to specific non-EU nationalities (Arrighi et al. 2013). As for emigrants, almost all Member States (except for Ireland, Denmark and Malta, with exceptions) allow their citizens residing abroad to vote in national parliamentary elections. ${ }^{22}$

In any case, the effect of migrants' pressure (via their demographic, economic or political leverage) on the openness of national welfare systems can also be mediated or constrained by the general characteristics of the latter. In this regard, it is important to note that the complexities of European welfare states make their classification into ideal types of social policy models a rather difficult task. Welfare scholars

${ }^{22}$ GLOBALCIT. Conditions for electoral rights. http://globalcit.eu/conditions-for-electoralrights/. Accessed 16 March 2020. 
have proposed different classifications (see Esping-Andersen 1990; Ferrera 1996; Bonoli 1997; Österman et al. 2019, among others). Denmark, Finland and Sweden are generally labelled under the Nordic social-democratic welfare model that combines strong universalism, solidarity, equality, strong but limited safety nets, highquality public healthcare services and high shares of social protection expenditure (Arts and Gelissen 2002; Kvist et al. 2012; Rice 2013). Austria, Belgium, Luxembourg, Germany, France or the Netherlands are usually clustered under the continental corporatist model based on Bismarkian insurance schemes, the security principle, generous unemployment benefits and general benefits based on one's prior contributions or occupational status (Arts and Gelissen 2002; Palier 2010; Österman et al. 2019). The Anglo-Saxon regime (defined by weak universalism, free healthcare services, social benefits for individuals in need- including the working poor- in which means-testing plays a significant role) is, in turn, observable in Ireland $^{23}$. On the other hand, Spain, Italy, Greece, Portugal or Cyprus share important features of the Mediterranean regime characterised by institutional fragmentation, significant role of family support in social protection provision, a developed social assistance system, and rather generous old-age pensions provisions (Ferrera 1996; Arts and Gelissen 2002). Finally, Central and Eastern European countries (most of which have adopted important social policy reforms since the 1990s) are generally considered as having a social protection model of their own. This often combines strong involvement of families as providers of social protection, low pensions level, rather hybrid health care schemes and strong emphasis on redistribution to prevent poverty (Österman et al. 2019).

This variety in the way in which EU states respond to the social protection needs of their populations by emphasizing the importance of certain policy areas over others is also reflected in their government expenditure on social protection (Fig. 1.6). Social protection still stands out as the main function of government expenditure in Europe, accounting for $18.8 \%$ of the GDP across the EU in 2017. Old-age pension payments represent a significant component of government expenditure $(10.1 \%$ of the GDP across all EU Member States in 2017), followed by sickness and disability (2.7\%), family and children (1.7\%), survivors (1.3\%) and unemployment (1.2\%). Overall, 15 current EU Member States (the Netherlands, Slovenia, Poland, Spain, Portugal, Luxembourg, Germany, Greece, Belgium, Sweden, Austria, Italy, Denmark, France, Finland) spent more than $15 \%$ on social protection in 2017, with the highest share being reached in Nordic countries and in France. However, the ratio of government expenditure on social protection to GDP is substantially smaller in Ireland, Lithuania, Malta, Latvia or Romania (less than $12 \%$ in each case).

In light of these different social policy frameworks, the share of people at risk of poverty or social exclusion (Fig. 1.7) also varies widely across EU Member States. In 2017, 22\% of resident EU nationals across all EU Member States were considered to be at risk of poverty or social exclusion. This share was even higher in $12 \mathrm{EU}$

\footnotetext{
${ }^{23}$ Although the Maltese welfare system is rather difficult to classify given its mixed character, it also shares some common characteristics with the Anglo-Saxon social protection system, mainly given the British legacy with emphasis on means-tested benefits (see Österman et al. 2019).
} 


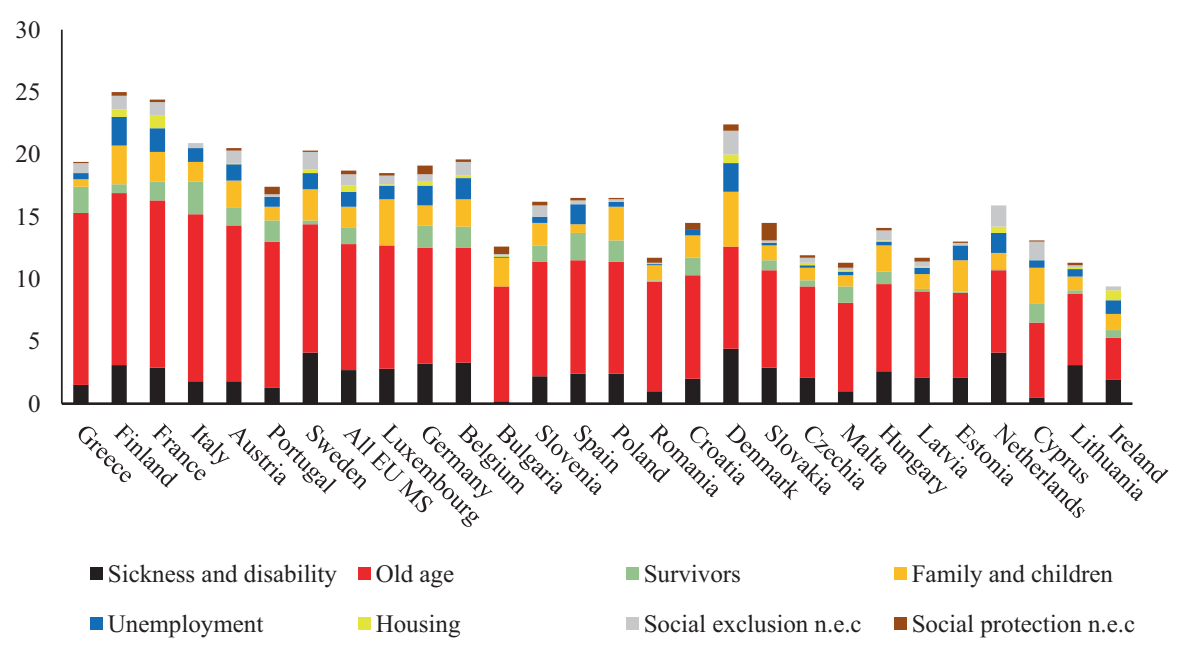

Fig. 1.6 Total general government expenditure on social protection (share of the GDP). (Source: Own elaboration based on the 2017 Eurostat data- General government expenditure by function (COFOG) [gov_10a_exp], https://ec.europa.eu/eurostat/data/database. Accessed 16 of March 2020)

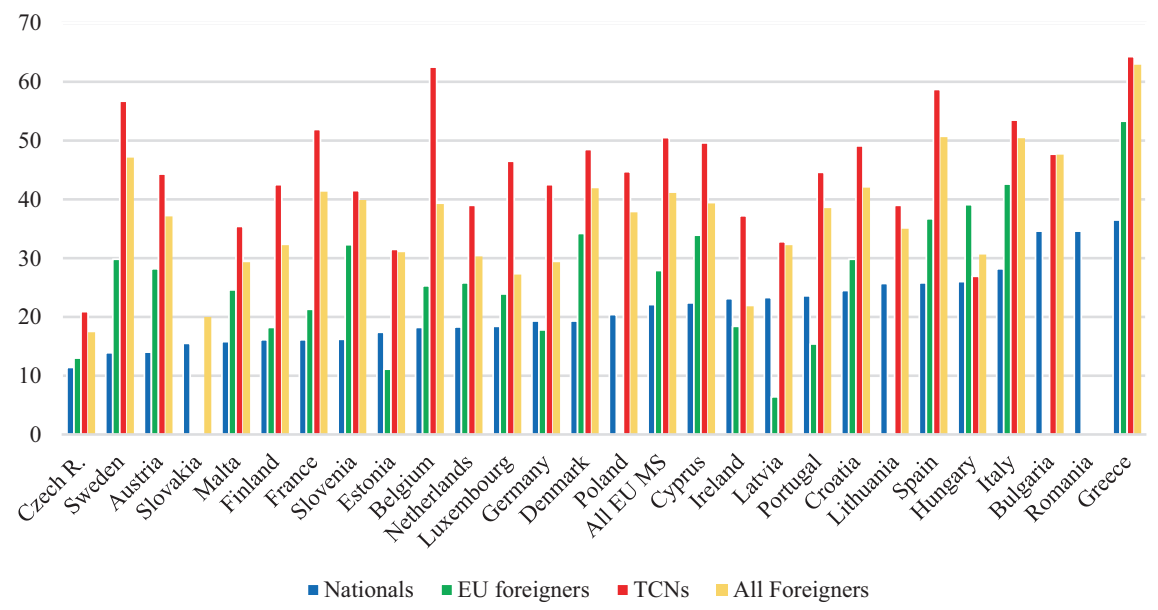

Fig. 1.7 Percentage of people at risk of poverty or social exclusion (18-64 years), by citizenship. (Source: Own elaboration based on the 2017 Eurostat data- People at risk of poverty or social exclusion by broad group of citizenship (population aged 18 and over [ilc_peps05], https://ec. europa.eu/eurostat/data/database. Accessed 16 of March 2020)

countries, reaching more than $30 \%$ in Bulgaria, Romania and Greece. Migrants tend to be even more vulnerable than national residents. Across all EU countries, the share of foreigners at risk of poverty or social exclusion was $41.1 \%$, up to $50.5 \%$ amongst third-country nationals. In France, Belgium, Spain, Italy, Greece and Sweden, more than a half of non-EU migrants were at risk of poverty or social 
exclusion (up to more than $60 \%$ in Belgium and Greece). In these countries, but also in Denmark, Austria or Slovenia, the gap between nationals and foreigners was particularly large (more than 20 difference points in the share of people at risk). Yet, this gap was smaller in Slovakia and Hungary (less than 5\%); and it was slightly reversed in Ireland, where the proportion of foreigners at risk of poverty was slightly lower when compared to nationals.

How are these different features of European welfare states expected to affect migrants' access to social protection? Currently, there is no scholarly agreement on this issue, as few arguments have been proposed so far on how social protection regimes influence migrants' social rights (see Morissens and Sainsbury 2005; Sainsbury 2006, 2012; Van Der Waal et al. 2013; Österman et al. 2019; Schmitt and Teney 2019). For instance, countries with more generous welfare policies may link service provision to habitual residence in their territory, thus automatically excluding non-residents (Bruzelius 2019). They may also be more cautious in granting immigrants' access to these generous welfare entitlements, especially in a context of fiscal pressures (Römer 2017). Other countries could appear as particularly restrictive towards immigrants' access to certain benefits simply because these benefits are granted under rather restrictive eligibility conditions for all claimants, including nationals. Finally, one could also expect that countries with universal healthcare services automatically open entitlement to these services also for foreigners. However, systems that are more generous in offering non-contributory means-tested benefits may be more restrictive towards migrants' access to these benefits by imposing more demanding residency conditions to avoid being more susceptible to attract migrants that would depend on their welfare provisions.

Of course, politicisation of migrants' access to welfare adds another layer of complexity by further incentivising restrictiveness in social policy regulations towards migrants, especially in countries with more generous welfare provisions. Building on the work of Andersen and Bjørklund (1990) on welfare chauvinism, scholars have looked at how right-wing populist parties combine sceptical discourses on immigration with favourable views on economic redistribution limited to the native population and "deserving migrants" (Rydgren 2004; Banting 2010; Van Der Waal et al. 2010). As shown in several case studies, mainstream parties often adjust their discourse on migration and welfare in response to the electoral success of these right-wing populist parties (Kitschelt and McGann 1995; de Lange 2007; Schumacher and van Kersbergen 2014). Whereas third-country nationals tend to become the main target of such discourses, one recent illustration of mainstream party adjustment to right-wing welfare chauvinist parties concerned mobile EU citizens. In 2013, a group of British, German, Austrian and Dutch ministers complained to the European Commission that some of their cities were 'under a considerable strain by certain immigrants from other member states'. The letter found support among various centre parties (the UK Conservatives, the French Les Republicains) that called for stricter controls, repatriation and the possibility to restrain the free movement of some EU citizens (Barbulescu et al. 2015). This episode demonstrates how politicization at EU level could aim to adjust supranational norms that protect immigrants' access to welfare. 
Departing from these general societal and welfare dynamics, the next section summarizes some of the main findings of this volume in terms of how EU Member States ensure the access to social benefits for their immigrant and emigrant populations.

\subsection{Comparing Levels of Inclusiveness across Countries and Between Groups: Main Patterns of Convergence and Divergence}

The empirical analyses developed in the country chapters included in this volume confirm the existence of several instances of policy convergence in the way in which European democracies legally define the access of their immigrant and emigrant populations to domestic welfare systems.

\subsubsection{Habitual Residence, Territoriality and Restrictiveness of Welfare Regimes towards Non-Residents}

To begin with, the country chapters show that, in general, EU Member States tend to be more inclined to grant residence-based welfare entitlements to foreigners when compared to nationality-based social benefits for their nationals residing abroad. As discussed in this volume, most Member States have implemented rather restrictive policies towards the access of their emigrant populations to social benefits. In fact, regardless of the size of the diaspora, the economic and political leverage of the later, or the type of welfare regime, European countries subscribe to the same pattern that disqualifies non-residents from most cash-related benefits. Their national boundaries still constitute the primary locus in which individuals can enjoy welfare provisions. This means that emigrants do not have a basic entitlement to various social benefits from their home countries just because they hold the status of nationals of these countries. On the contrary, given that most social benefits are conditional upon residence in the country that grants them, exportability is rarely possible and generally levied only on grounds of international conventions, the European social security coordination system, or bilateral social security agreements signed with third countries. This finding thus confirm a pattern already highlighted in previous studies (see, for instance, Guiraudon 2002) of a decline in the relevance of nationality for accessing welfare, compared to the strengthening of residency-related conditions.

This strong emphasis on residence in access to social protection that directly hinders emigrants' eligibility for social benefits from their countries of nationality is observed across most policy areas analyzed here. Although short-term temporary stays abroad are generally allowed in particular circumstances (for instance, for the purpose of medical treatment abroad or for holidays), when individuals leave their 
EU countries of nationality to permanently settle abroad, they usually lose their entitlement to social benefits from these countries. ${ }^{24}$ As an illustration, access to the health care system or sickness cash benefits is usually based on the principle of territoriality and generally granted only to those habitually residing or working in a particular country. Consequently, moving abroad permanently usually terminates membership to the health care system of the country of nationality. In the same vein, residence in the country generally conditions access to unemployment benefits, non-contributory pensions, family-related benefits and especially so, guaranteed minimum resources. For instance, none of the EU Member States that implements non-categorical assistance schemes aiming to guarantee a minimum income to all those in need allow their nationals residing abroad to claim these benefits, as recipients must effectively reside in these countries. In some cases (see the example of Cyprus in this volume), this effective residence criterion for claiming social assistance is further complemented by a minimum period of prior and continuous residence in the country, this additional element constraining even the access of returnees to this specific benefit.

\subsubsection{Differentiated Exclusion: Waiving the Residence Condition for Emigrants}

Despite this general trend pointing towards the restrictiveness of national social policy legislations towards non-resident citizens, the EU coordination system allows mobile EU citizens to continue receiving certain benefits from their countries of nationality while residing in another EU country, thus shifting the restrictive understanding of welfare as a territorial responsibility. One obvious example is the possibility of EU citizens to retain (for a short period) their unemployment benefits when moving to an EU/EEA (European Economic Area) country for the purposes of finding a job ${ }^{25}$. Additionally, EU nationals also enjoy non-discriminatory access to most welfare entitlements in their EU countries of residence. Given that, as previously mentioned, most Europeans living outside their countries of nationality reside in other EU Member States, this supranational framework guarantees their access to social protection even in absence of targeted national policies to ensure their inclusion in the domestic welfare system of their origin countries.

Moreover, although eligibility for most social benefits is built on residence, some exceptions (or waivers of the territoriality condition) can still be identified across specific policy areas, thus indicating a certain selectivity in the exclusion of emigrants from domestic welfare systems. By way of example, invalidity benefits can

\footnotetext{
${ }^{24}$ This excludes, of course, the case of individuals who reside abroad while still working in the service of employers based in the country of nationality, a group that is specifically excluded from our analysis.

${ }^{25}$ Regulation (EC) No. 883/2004 and Regulation (EC) No. 987/2009. See also: https://europa.eu/ youreurope/citizens/work/unemployment-and-benefits/transferring-unemployment-benefits/ index_en.htm. Accessed 16 of March 2020.
} 
often be exported worldwide (see, for instance, the chapters on Ireland, Malta or Romania) although, in some cases (France, Belgium or Poland), they can only be transferred within the EU, unless otherwise stipulated in bilateral agreements with third countries. Contributory old-age pensions also stand out as an important exception to the strong link between residence and access to benefits across the $\mathrm{EU}^{26}$, while also representing one of the most important components of government expenditure across EU countries (Fig. 1.6 above). Unlike other cash payments, contributory old-age pensions can generally be transferred to both EU and non-EU countries (see the chapters on Austria, Croatia, Finland, France, Hungary, Ireland, Lithuania, Malta, the Netherlands, Portugal, Spain, Slovakia or Sweden). ${ }^{27}$ Yet, some Member States (such as Bulgaria or the Czech Republic) still constrain nonresident nationals' possibility to transfer these pensions to third countries on the existence of bilateral agreements with the latter; whereas the Netherlands conditions the amount received after the transfer of the contributory pension to the existence of such bilateral conventions. Additionally, some EU Member States also offer specific public non-contributory pension schemes. However, as discussed in the country chapters in this volume, access to these pensions usually depends on residence in the country. Thus, non-resident nationals are excluded as potential claimants (with some exceptions- see the chapter on Spain for details regarding the means-tested non-contributory pension that the Spanish authorities make available to elderly non-resident nationals who cannot work due to illness and do not receive a contributory pension from the home or host country). Nevertheless, the general tendency of exclusiveness of social policy legislations towards diaspora populations is sometimes partly compensated by specific policies or programs that European states develop in the attempt to respond to certain social protection needs of their nationals abroad (for an in-depth discussion of such programs, see Lafleur and Vintila 2020a).

\subsubsection{Equal Access for Foreign Residents in Social Policy Regulations, but Modes of Exclusion via Immigration Policies and the Labour Market}

States' restrictive behaviour towards diaspora populations does not necessarily correlate with their policy stances towards foreign residents. Our findings indicate that most European states tend to be rather inclusive in granting equal access of nonnational residents to welfare benefits, thus responding to a residence-driven rationale (rather than a nationality-driven philosophy) in the design of the eligibility conditions to access social rights. However, there are still important exceptions

\footnotetext{
${ }^{26}$ For conditions of retiring abroad within the EU, see also Regulation (EC) No. 883/2004, Regulation (EC) No. 987/2009 and https://europa.eu/youreurope/citizens/work/retire-abroad/ state-pensions-abroad/index_en.htm (accessed 16 of March 2020).

${ }^{27}$ In general, recipients are required to follow the procedure of the proof of life to receive their pensions abroad.
} 
from this pattern of social inclusion based on territoriality, such exceptions being mostly visible in the area of non-contributory benefits and especially affecting thirdcountry nationals.

As discussed in the country chapters, nationality is of rather minor importance once foreigners obtain access to employment in their EU countries of residence. Broadly speaking, social security laws do not distinguish between claimants based on their nationality, they do not reserve social benefits only for nationality holders, nor do they explicitly impose specific migration-related conditions that could directly obstruct immigrants' access to welfare. Entitlement to most benefits derives from employment or qualifying periods of contribution to the social security system of the EU countries of residence, rather than being conditional upon nationality. Gainful activity thus becomes a decisive element for accessing contributory benefits and as soon as a person starts contributing to the social security system of most EU countries, he/she has equal access to benefits with the national citizens of those countries.

Yet, complying with the qualifying period of contribution or employment required for accessing social benefits may be more problematic for foreign workers compared to their national counterparts. This is especially the case when considering immigrants' employment vulnerability. For instance, the unemployment rates of foreigners (especially third-country nationals) across the EU have been consistently higher when compared to the unemployment rates of non-mobile EU citizen ${ }^{28}$ and important obstacles (lack of recognition of qualifications obtained abroad, labour market discrimination, etc.) still prevent migrants from finding suitable jobs in their EU host countries ${ }^{29}$. Additionally, holding a valid work permit does not always follow an easy procedure given the variation in the regulations applicable in this regard across the EU. Hence, although social policy regulations may not directly exclude foreigners from national welfare systems, domestic immigration policies regulating the right to enter, reside and work in a particular country or general labour market inequalities between migrants and non-migrants could still lead to modes of exclusion from welfare entitlements. This reinforces the findings of previous studies regarding the importance of immigration policies in imposing different levels of conditionality that could affect foreigners' access to welfare (Sainsbury 2012; Shutes 2016; Bruzelius 2019; Schmitt and Teney 2019).

However, the type of benefits is another important element to be considered. Our findings generally confirm the initial expectation that states are more likely to restrict the access of mobile individuals (especially TCNs, who are also at higher risk of poverty and social exclusion) to non-contributory benefits when compared to the contributory ones. The country chapters show that benefits typically linked to

\footnotetext{
${ }^{28}$ Eurostat (2019). Migrant integration statistics- labour market indicators (lfsa_urgacob and lfsa_ urgan). https://ec.europa.eu/eurostat/statistics-explained/index.php/Migrant_integration_ statistics_\%E2\%80\%93_labour_market_indicators\#Unemployment. Accessed 16 of March 2020.

${ }^{29}$ Eurostat (2017). Migrant integration: 2017 edition. https://ec.europa.eu/eurostat/documents/3217494/8787947/ KS-05-17-100-EN-N.pdf/f6c45af2-6c4f-4ca0-b547-d25e6ef9c359. Accessed 16 of March 2020.
} 
employment tend to be open to all claimants on equal grounds (regardless of their nationality), although with some exceptions. For instance, most countries have no statutory differences between the eligibility requirements for accessing a contributory pension applied for national and foreign residents. However, some differences exist in terms of the possibility to export such pension. By way of example, unlike their national or EU counterparts, third-country nationals receiving a contributory pension from Belgium or Luxembourg cannot generally export it (with some exceptions); whereas those receiving a contributory pension from Lithuania can transfer it only when moving to a country that has concluded a bilateral agreement with Lithuania.

In general, foreigners residing in EU Member States can also access cash benefits in case of sickness as well as maternity, paternity or unemployment benefits under the same eligibility conditions as those applied for national residents. For unemployment benefits in particular, EU citizens can also aggregate the periods spent in other EEA countries for complying with the requirement of prior contribution required to qualify for these benefits in the new EU country of residence. As discussed in the chapter on Denmark, this also implies that an EU migrant worker can have more immediate access to Danish unemployment benefits than the national worker who stayed in Denmark. This situation has become a key issue of debate in Danish politics, despite the condition applied in Denmark that individuals must be members of the Danish unemployment insurance fund for three months before using the principle of aggregation, a condition aiming to prevent EU citizens' immediate access to the unemployment scheme.

The situation is even more nuanced for third-country nationals as in some cases, national provisions put them in a disadvantaged position for accessing unemployment benefits compared to mobile EU citizens. For instance, TCNs must hold the long-term residence status to qualify for unemployment benefits in Bulgaria, whereas in France, they are required to prove regular residence that is strictly assessed based on the type of residence permits they possess. The Danish legislation also requires claimants of unemployment benefits to have resided seven years out of the last 12 years in Denmark. Although this prerequisite applies to nationals and foreigners alike, it still puts TCNs in a more vulnerable position, especially since periods spent in non-EU countries do not count for the seven years requirement (unlike periods spent in the EU). Furthermore, in Malta, third-country nationals who are not permanent residents cannot access unemployment benefits, as they are unable to register for work at the employment service, which, in turn, is a requirement for receiving unemployment benefits.

\subsubsection{Immigrants'Access to Non-contributory Benefits: More Instances of Direct Exclusion}

The situation is much more complex when it comes to foreigners' access to noncontributory benefits that in many cases, has become a sensitive and rather controversial issue in political and societal debates. In fact, it is in the area of non-contributory 
benefits in which states show more direct or indirect forms of exclusion of nonnational residents from domestic welfare systems. In this particular area, claimants' nationality remains an important element conditioning their access to welfare. For example, whereas in some countries, EU and non-EU foreigners are entitled to access guaranteed minimum resources schemes under the same eligibility conditions as national residents (see the examples of Austria or Ireland), in others, residence-related clauses can directly hinder foreigners (especially TCNs with limited prior residence) from claiming such benefits. To qualify for social assistance in Belgium (a country in which the share of migrants at risk of poverty and social exclusion is particularly high- Fig. 1.7 above), EU citizens must have resided for at least three months, whereas third-country nationals must be registered in the Belgian population register (which is usually possible only after five years of residence). Similar situations are identified in Croatia, Lithuania, Slovenia, Cyprus or Luxembourg, where TCNs' access to social assistance is made conditional upon a prior residence period of at least five years or having obtained the permanent resident status. In Portugal, unlike national residents or EU citizens, third-country nationals are also required to have resided for at least a year to be able to claim social assistance. Some countries also condition access to social assistance for all claimants to a minimum period of prior residence (five years in Cyprus or seven out of the last eight years in Denmark), a requirement that can be particularly challenging for migrants, especially third-country nationals. Sometimes, access to guaranteed minimum resources schemes is also restricted for EU nationals: as explained in this volume for the German case, EU citizens who enter Germany as jobseekers or non-employed cannot claim the Minimum Income for Non-Participants.

As discussed above, non-contributory pensions represent another social protection area in which some EU Member States put forward more restrictive eligibility conditions that mainly affect individuals who find themselves in a situation of international mobility. In some cases, non-EEA residents are directly excluded as potential beneficiaries of such pensions. Examples come from Belgium or Portugal, where non-EEA residents cannot claim a non-contributory pension unless specifically provided for via bilateral agreements; but also Malta, where TCNs do not qualify for such pensions unless they are long-term residents. In other cases, even when the eligibility conditions for accessing a social pension are the same between nationals and foreigners, strict residence provisions still apply. As an illustration, a qualifying residence period of three years is required to access non-contributory pensions in Finland, whereas in Estonia or Italy, this period is extended to five and ten years, respectively. Similarly, social pension recipients in Cyprus must be permanent residents and have resided in Cyprus/EU/EEA/Switzerland for at least 20 years after the age of 40 or at least 35 years after the age of 18. In France, TCNs must prove regular and continuous residence with an authorisation to work for at least ten years to qualify for non-contributory pensions. Thus, by linking noncontributory pension schemes to residence conditionality, these countries explicitly exclude elderly migrants who arrived more recently, although some of them may still qualify for the general guaranteed minimum resource schemes offered by some of these host countries. 
Finally, unlike maternity and paternity benefits that foreigners can generally access under the same conditions as those applied for national residents, access to child benefits across the EU is often conditioned by residence requirements. ${ }^{30}$ For instance, the child allowance in Croatia is available to the parent of the child who has uninterrupted residence in the country for at least three years prior to the application. As explained in the chapters on Bulgaria, Romania, Malta, Luxembourg, Finland, Sweden, the Netherlands or Portugal, children are also generally required to reside in these countries to receive child benefits (with exceptions of residence in other EU states or countries covered by bilateral agreements). In Cyprus, nationals and foreigners alike must have resided legally and continuously in the country for five years before applying for child benefits; whereas in Lithuania, TCNs with temporary residence permits are eligible for child benefits if they have worked for at least six months or are registered at the Employment Service if unemployed. Denmark also requires a certain period of prior residence to qualify for family benefits: six months of residence or employment in the past ten years to qualify for the universal child benefit and one-three years of residence to be eligible for the child allowance. As explained in the country chapter, access to family benefits has become a recurrent topic in Danish politics, especially given the demands of the Danish People's Party (DPP) to restrict EU citizens' right to child benefits. Denmark is not an isolated case in this regard, as migrants' access to family benefits has become a politically sensitive issue across the EU (see also Strban 2016). Similar restrictive proposals also gained salience and raised tensions in other Member States, especially Western European countries with sizeable immigrant communities. For instance, the right-wing candidate for the 2017 presidential elections in France proposed to make the regular residence condition for accessing family benefits more restrictive, whereas the EU launched the infringement procedure against Austria for trying to adapt family benefits to the costs of living in the child's country of residence.

\subsubsection{The Negative Consequences of Take-Up of Social Benefits}

Even when foreigners are entitled to claim benefits on equal grounds with their national counterparts, their access to welfare may still be indirectly constrained by the potential negative consequences that the take-up of such benefits could have for other migration-related entitlements. As discussed in some country chapters (see Belgium, France, Ireland, Greece or Finland), reliance on social assistance is often considered as a burden on public funds. In turn, this can negatively affect the renewal of migrants' residence permits, their applications for family reunification, or even

\footnotetext{
${ }^{30}$ For the EU provision on coordination of family benefits, see Regulation (EC) No 883/2004 and Regulation (EC) No 987/2009. See also: https://europa.eu/youreurope/citizens/work/unemployment-and-benefits/family-benefits/index_en.htm. Accessed 16 of March 2020.
} 
their citizenship applications, as the latter generally depend on conditions of social integration and proving one's stable income and self-sufficiency. This creates an extra layer of conditionality that could affect foreigners' practical access to welfare (see also Lafleur and Mescoli 2018 on the practice of residence permits removal for EU nationals claiming certain welfare benefits in Belgium). Finally, as highlighted in some chapters, even when migrants do benefit from equal access to welfare, the required eligibility criteria (including qualifying periods of contribution/employment, waiting periods, type of documents supporting the application or the general application procedure) can still make it more difficult for migrants to access benefits when compared to non-migrants.

Summing up, country chapters included in this volume point towards interesting variations in the way in which EU Member States respond to the social protection needs of their immigrant and emigrant populations. Although national welfare regimes usually seem more inclusive towards non-national residents when compared to non-residents nationals, significant differences still exist in the regulations conditioning foreigners' access to benefits. In general, our results indicate that EU coordination rules neutralise potential legal barriers for mobile EU citizens' access to welfare (although there are still some exceptions, such as the lack of full harmonisation of the Croatian legislation to ensure equal treatment for EU nationals in terms of accessing welfare). In many cases, this also confirms the initial expectation according to which the EU social security coordination and the principle of equal treatment and non-discrimination of mobile EU citizens place this group in a better position to access social benefits when compared to non-EU migrants, thus creating different tiers of entitlement to welfare. Indeed, the process of mapping out TCNs' right to social protection across the EU reveals important gaps in terms of access, especially when it comes to benefits that are not traditionally linked to employment or contributions to the host countries' social security system. Whereas in some countries, (certain categories of) TCNs are directly excluded from the list of potential beneficiaries of specific benefits, in others, much subtler mechanisms of exclusion can be observed. Overall, these findings still show the existence of significant inequalities in access to social protection for individuals coming to or moving out of the EU. The country chapters included in the rest of the volume aim precisely at highlighting and contextualising the complexities of such inequalities.

\subsection{Structure of the Volume}

The rest of the volume includes 27 country chapters, one per each EU Member State. Each chapter starts with a general discussion regarding the evolution and main characteristics of the national welfare system, thus analyzing the type of social protection regime operating in each country, recent social policy reforms and the main contributory and non-contributory benefits applicable in each case. This first part is followed by a contextualization of the history of immigration and emigration of each Member State, with each chapter providing information regarding the evolution of migration flows, main countries of origin and destination of immigrants/ 
emigrants, as well as the main type(s) of migration (labour migration, lifestyle migration, family reunification, etc.).

After this introductory section that provides a contextualization of each case study, each chapter examines the main eligibility conditions for accessing social benefits for national residents, non-national residents and non-resident nationals. The main findings are interpreted in relation to key migration patterns and the type of welfare regime. All chapters focus specifically on five core policy areas: unemployment, health care, pensions, family-related benefits and guaranteed minimum resources. For each type of benefit, authors explain how national and non-national beneficiaries are legally defined in national legislations, which are the qualifying periods of insurance, residence, or age for accessing these schemes, the characteristics of means-tested programs versus those granted on a universal basis, and the duration of benefits. The chapters also provide an in-depth discussion of situations in which access to welfare is conditioned by nationality (with foreigners receiving a differentiated treatment when compared to nationals) or residence (with nonresident nationals being excluded from certain benefits due to exportability regulations). Authors also discuss migration-related requirements (specific residence permits, authorisations of stay, visas, having a fixed domicile, etc.) that could hinder immigrants' and emigrants' possibility to access social protection; while also emphasizing how bilateral social security arrangements between home and host countries could ensure better protection against social risks for mobile individuals.

Acknowledgements This chapter is part of the project "Migration and Transnational Social Protection in (Post)Crisis Europe (MiTSoPro)" that has received funding from the European Research Council (ERC) under the European Union's 2020 research and innovation programme (Grant agreement No. 680014). In addition to this chapter, readers can find a series of indicators comparing national social protection and diaspora policies across 40 countries on the following website: http://labos.ulg.ac.be/socialprotection/. We wish to thank Angeliki Konstantinidou for her assistance in compiling the international migration data used in this chapter.

\section{References}

Andersen, J. G., \& Bjørklund, T. (1990). Structural changes and new cleavages: The progress parties in Denmark and Norway. Acta Sociologica, 33(2), 195-217.

Arrighi, J.-T., Bauböck, R., Collyer, M., Hutcheson, D., Moraru, M., Khadar, L., \& Shaw, J. (2013). Franchise and electoral participation of third country citizens residing in the European Union and of EU citizens residing in third countries. Available at: https://www.europarl.europa. eu/thinktank/en/document.html?reference=IPOL-AFCO_ET(2013)474441. Accessed 05 May 2020.

Arts, W., \& Gelissen, J. (2002). Three worlds of welfare capitalism or more? A state-of-the-art report. Journal of European Social Policy, 12(2), 137-158.

Avato, J., Koettl, J., \& Sabates-Wheeler, R. (2010). Social security regimes, global estimates, and good practices: The status of social protection for international migrants. World Development, 38(4), 455-466.

Banting, K. G. (2010). Is there a progressive's dilemma in Canada? Immigration, multiculturalism and the welfare state: Presidential address to the Canadian Political Science Association, Montreal, June 2, 2010. Canadian Journal of Political Science, 43(4), 797-820. https://doi. org/10.1017/S0008423910000983. 
Barbulescu, R., Lafleur, J.-M., \& Stanek, M. (2015). Intra-European mobility: Patterns of immigration flows and policies. Western Europe, 2016, 35-39.

Barglowski, K., Bilecen, B., \& Amelina, A. (2015). Approaching transnational social protection: Methodological challenges and empirical applications. Population, Space and Place, 21(3), 215-226. https://doi.org/10.1002/psp.1935.

Bird, K., Saalfeld, T., \& Wüst, A. M. (2011). The political representation of immigrants and minorities: Voters, parties and parliaments in liberal democracies. New York: Routledge.

Blauberger, M., \& Schmidt, S. (2014). Welfare migration? Free movement of EU citizens and access to social benefits. Research and Politics, I, 7. https://doi.org/10.1177/2053168014563879.

Bommes, M., \& Geddes, A. (2000). Immigration and welfare. Challenging the borders of the welfare state. New York: Routledge.

Bonoli, G. (1997). Classifying welfare states: A two-dimension approach. Journal of Social Policy, 26(3), 351-372.

Borjas, G. J. (1998). Immigration and welfare magnets. Journal of Labor Economics, 17(4), 607-637.

Bruzelius, C. (2019). Freedom of movement, social rights and residence-based conditionality in the European Union. Journal of European Social Policy, 29(1), 70-83. https://doi. org/10.1177/0958928718756262.

de Lange, S. L. (2007). A new winning formula? The programmatic appeal of the radical right. Party Politics, 13(4), 411-435.

Deacon, B., \& Nita, S. (2013). Regional social integration and free movement across borders: The role of social policy in enabling and preventing access to social entitlements by cross-border movers. European Union and Southern Africa compared. Regions \& Cohesion, 3(1), 32-61.

Eisele, K. (2018). Social security coordination in association agreements: Is a common EU approach with third countries in sight? European Journal of Social Security, 20(2), 116-128. https://doi.org/10.1177/1388262718771785.

Esping-Andersen, G. (1990). The three worlds of welfare capitalism. Cambridge: Polity Press.

Ferrera, M. (1996). The "Southern" model of welfare in social Europe. Journal of European Social Policy, 6(1), 17-37.

Freeman, G. P. (1986). Migration and the political economy of the welfare state. The Annals of the American Academy of Political and Social Science, 485, 51-63.

Gamlen, A. (2008). The emigration state and the modern geopolitical imagination. Political Geography, 27, 840-856.

Giulietti, C. (2014). The welfare magnet hypothesis and the welfare take-up of migrants (pp. 1-37). Bonn: IZA World of Labor. https://doi.org/10.15185/izawol.37.

Guiraudon, V. (2002). Including foreigners in national welfare states: Institutional venues and rules of the game. In B. Rothstein \& S. Steinmo (Eds.), Restructuring the welfare state: Political institutions and policy change. New York: Palgrave.

Holzmann, R. (2016). Do bilateral social security agreements deliver on the portability of pensions and health care benefits? A summary policy paper on four migration corridors between EU and non-EU member states. IZA Journal of European Labor Studies, 5(17), 1-35.

Holzmann, R., Koettl, J., \& Chernetsky, T. (2005). Portability regimes of pension and health care benefits for international migrants. An analysis of issues and good practices. World Bank Social Protection Research Paper. Geneva: Global Commission on International Migration.

Kitschelt, H., \& McGann, A. (1995). The radical right in Western Europe: A comparative analysis. Ann Arbor: University of Michigan Press.

Koopmans, R., \& Michalowski, I. (2017). Why do states extend rights to immigrants? Institutional settings and historical legacies across 44 countries worldwide. Comparative Political Studies, 50(1), 41-74. https://doi.org/10.1177/0010414016655533.

Kramer, D., Thierry, J., \& van Hooren, F. (2018). Responding to free movement: Quarantining mobile union citizens in European welfare states. Journal of European Public Policy, 25(10), 1501-1521. https://doi.org/10.1080/13501763.2018.1488882.

Kvist, J., Fritzell, J., Hvinden, B., \& Kangas, O. (Eds.). (2012). Changing social equality: The Nordic welfare model in the 21st century. Bristol: Policy Press. 
Lafleur, J.-M. (2013). Transnational politics and the state. The external voting rights of diasporas. New York: Routledge.

Lafleur, J.-M., \& Mescoli, E. (2018). Creating undocumented EU migrants through welfare: A conceptualization of undeserving and precarious citizenship. Sociology, 52(3), 480-496. https://doi.org/10.1177/0038038518764615.

Lafleur, J.-M., \& Stanek, M. (2017). Restrictions to social protection by new Southern European migrants in Belgium. In J.-M. Lafleur \& M. Stanek (Eds.), South-north migration of EU citizens in times of crisis (IMISCOE Research Series) (pp. 99-121). https://doi. org/10.1007/978-3-319-39763-4_7.

Lafleur, J.-M., \& Vintila, D. (Eds.). (2020a). Migration and social protection in Europe and beyond (Volume 2): Comparing consular services and diaspora policies. Cham: Springer.

Lafleur, J.-M., \& Vintila, D. (Eds.). (2020b). Migration and social protection in Europe and beyond (Volume 3): A focus on non-EU sending states. Cham: Springer.

Lafleur, J.-M., \& Vivas Romero, M. (2018). Combining transnational and intersectional approaches to immigrants' social protection: The case of Andean families' access to health. Comparative Migration Studies, 6(1), 14. https://doi.org/10.1186/s40878-018-0073-7.

Larsen, J. E. (2005). The active society and activation policy: Ideologies, contexts and effects. In J. G. Andersen, A.-M. Guillemard, P. H. Jensen, \& B. Pfau-Effinger (Eds.), The changing face of welfare: Consequences and outcomes from a citizenship perspective (pp. 135-150). Bristol: Bristol University Press.

Levitt, P., Viterna, J., Mueller, A., \& Lloyd, C. (2017). Transnational social protection: Setting the agenda. Oxford Development Studies, 45(1), 2-19. https://doi.org/10.1080/13600818.201 6.1239702 .

Maas, W. (2007). Creating European citizens. Lanham: Rowman \& Littlefield.

Martinsen, D. S. (2005). The Europeanization of welfare - The domestic impact of intra-European social security. Journal of Common Market Studies, 43(5), 1027-1054.

Morissens, A., \& Sainsbury, D. (2005). Migrants' social rights, ethnicity and welfare regimes. Journal of Social Policy, 34(4), 637-660. https://doi.org/10.1017/S0047279405009190.

Österman, M., Palme, J., \& Ruhs, M. (2019). National institutions and the fiscal impact of EU migrants. Working Paper REMINDER Project. Available at: https://www.reminder-project.eu/ wp-content/uploads/2019/02/REMINDER-D4.3-Institutions-and-Fiscal-Effects.pdf. Accessed 05 May 2020.

OECD (2015). Connecting with emigrants: A global profile of diasporas. Paris: OECD Publishing.

Palier, B. (Ed.). (2010). A long goodbye to Bismarck? The politics of welfare reform in continental Europe. Amsterdam: Amsterdam University Press.

Rice, D. (2013). Beyond welfare regimes: From empirical typology to conceptual ideal types. Social Policy \& Administration, 47, 93-110. https://doi.org/10.1111/spol.12001.

Römer, F. (2017). Generous to all or 'insiders only'? The relationship between welfare state generosity and immigrant welfare rights. Journal of European Social Policy, 27(2), 173-196. https:// doi.org/10.1177/0958928717696441.

Ruhs, M., \& Palme, J. (2018). Institutional contexts of political conflicts around free movement in the European Union: A theoretical analysis. Journal of European Public Policy, 25(10), 1481-1500. https://doi.org/10.1080/13501763.2018.1488883.

Rydgren, J. (2004). Explaining the emergence of radical right-wing populist parties: The case of Denmark. West European Politics, 27(3), 474-502. https://doi.org/10.108 0/0140238042000228103.

Sabates-Wheeler, R., \& Feldman, R. (2011). Migration and social protection claiming social rights beyond borders. Basingstoke: Palgrave Macmillan.

Sabates-Wheeler, R., \& Koettl, J. (2010). Social protection for migrants: The challenges of delivery in the context of changing migration flows. International Social Security Review, 63, 115-144. https://doi.org/10.1111/j.1468-246X.2010.01372.x.

Sainsbury, D. (2006). Immigrants' social rights in comparative perspective: Welfare regimes, forms in immigration and immigration policy regimes. Journal of European Social Policy, 16(3), 229-244. https://doi.org/10.1177/0958928706065594. 
Sainsbury, D. (2012). Welfare states and immigrant rights. In The politics of inclusion and exclusion. Oxford: Oxford University Press.

Schmidt, S., Blauberger, M., \& Martinsen, D. S. (2018). Free movement and equal treatment in an unequal union. Journal of European Public Policy, 25(10), 1391-1402. https://doi.org/10.108 0/13501763.2018.1488887.

Schmitt, C., \& Teney, C. (2019). Access to general social protection for immigrants in advanced democracies. Journal of European Social Policy, 29(1), 44-55. https://doi. org/10.1177/0958928718768365.

Schumacher, G., \& van Kersbergen, K. (2014). Do mainstream parties adapt to the welfare chauvinism of populist parties? Party Politics, 22(3), 300-312. https://doi.org/ $10.1177 / 1354068814549345$.

Seeleib-Kaiser, M., \& Pennings, F. (2018). Intra-EU migration and social rights: An introduction. In M. Seeleib-Kaiser \& F. Pennings (Eds.), EU citizenship and social rights. Cheltenham: Edward Elgar Publishing. https://doi.org/10.4337/9781788112710.00008.

Serra Mingot, E., \& Mazzucato, V. (2017). Mobile populations in immobile welfare systems: A typology of institutions providing social welfare and protection within a mobility framework. The European Journal of Development Research, 29(4), 787-805. https://doi.org/10.1057/ s41287-016-0061-4.

Shaw, J. (2007). The transformation of citizenship in Europe: Electoral rights and the restructuration of the political space. Cambridge: Cambridge University Press.

Shutes, I. (2016). Work-related conditionality and the access to social benefits of national citizens, EU and non-EU citizens. Journal of Social Policy, 45(4), 691-707. https://doi.org/10.1017/ S0047279416000234.

Strban, G. (2016). Family benefits in the EU: Is it still possible to coordinate them? Maastricht Journal of European and Comparative Law, 23(5), 775-795. https://doi.org/10.117 7/1023263X1602300503.

Van der Waal, J., Achterberg, P., Houtman, D., de Koster, W., \& Manevska, K. (2010). 'Some are more equal than others': Economic egalitarianism and welfare chauvinism in the Netherlands. Journal of European Social Policy, 20(4), 350-363. https://doi.org/10.1177/0958928710374376.

Van Der Waal, J., De Koster, W., \& Van Oorschot, W. (2013). Three worlds of welfare chauvinism? How welfare regimes affect support for distributing welfare to immigrants in Europe. Journal of Comparative Policy Analysis: Research and Practice, 15(2), 164-181. https://doi.org/10.108 0/13876988.2013.785147.

Vintila, C. D. (2015). The European citizenship and the electoral rights of non-national EU citizens in the EU Member States. PhD dissertation, Universidad Autónoma de Madrid, Madrid.

Vintila, D., \& Morales, L. (2018). La representación política de las personas de origen inmigrante en España e Italia. Papers, 103(4), 521-550. https://doi.org/10.5565/rev/papers.2505.

Walzer, M. (1983). Spheres of justice: A defence of pluralism and equality. New York: Basic Books.

Open Access This chapter is licensed under the terms of the Creative Commons Attribution 4.0 International License (http://creativecommons.org/licenses/by/4.0/), which permits use, sharing, adaptation, distribution and reproduction in any medium or format, as long as you give appropriate credit to the original author(s) and the source, provide a link to the Creative Commons license and indicate if changes were made.

The images or other third party material in this chapter are included in the chapter's Creative Commons license, unless indicated otherwise in a credit line to the material. If material is not included in the chapter's Creative Commons license and your intended use is not permitted by statutory regulation or exceeds the permitted use, you will need to obtain permission directly from the copyright holder.

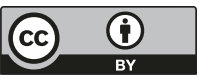

